\title{
Minimal intervention dentistry: part 3. Paediatric dental care - prevention and management protocols using caries risk assessment for infants and young children
}

\author{
F. J. Ramos-Gomez, ${ }^{1}$ Y. O. Crystal, ${ }^{2}$ S. Domejean ${ }^{3}$ and J. D. B. Featherstone ${ }^{4}$
}

IN BRIEF

- Examines the problem of early childhood caries and how it can be minimised.

- Informs caries is a transmissible, infectious disease, which can be passed from mother to child.

- Stresses the importance of risk assessment and preventive dentistry in paediatric healthcare.

\section{VERIFIABLE CPD PAPER}

Recent increases in caries prevalence in young children throughout the world highlight the need for a simple but effective infant oral care programme. This programme needs to include a medical disease prevention management model with an early establishment of a dental home and a treatment approach based on individual patient risk. This article presents an updated approach with practical forms and tools based on the principles of caries management by risk assessment, CAMBRA. This method will aid the general practitioner to develop and maintain a comprehensive protocol adequate for infant and young children oral care visits. Perinatal oral health is vitally important in preventing early childhood caries (ECC) in young children. Providing dental treatment to expectant mothers and their young children in a 'dual parallel track' is an effective innovative strategy and an efficient practice builder. It promotes prevention rather than intervention, and this may be the best way to achieve long-lasting oral health for young patients. General dental practice can adopt easy protocols that will promote early preventive visits and anticipatory guidance/counselling rather than waiting for the need for restorative treatment.

\begin{tabular}{l} 
MINIMAL INTERVENTION \\
DENTISTRY \\
\hline 1. From 'compulsive' restorative dentistry to \\
rational therapeutic strategies \\
2. Caries risk assessment in adults \\
3. Paediatric dental care - prevention and \\
management protocols using caries risk \\
assessment for infants and young children \\
4. Detection and diagnosis of initial \\
caries lesions \\
5. Atraumatic restorative treatment (ART) - \\
a minimum intervention and minimally \\
invasive approach for the management \\
of dental caries \\
6. Caries inhibition by resin infiltration \\
7. Minimally invasive operative caries \\
management - rationale and techniques \\
This paper is adapted from: Ramos-Gomez FJ, Crystal Y 0 , \\
Doméjean $S$, Featherstone $J D$ B. Odontologie pédiatrique. \\
Prevention et prise en charge de la maladie carieuse basees \\
sur 'évaluation du risque pour les jeunes enfants. Réalités \\
Cliniques $2011 ; 22$ (3): 221-232.
\end{tabular}

${ }^{2}$ University of California, Los Angeles, USA; ${ }^{2} \mathrm{New}$ York University, USA; ${ }^{3} \mathrm{CHU}$ Clermont-Ferrand, Service d'Odontologie, Hôtel-Dieu, F-63,001 Clermont-Ferrand, France; ${ }^{4}$ University of California, San Francisco, USA ${ }^{*}$ Correspondence to: Francisco Ramos-Gomez Email: frg@dentistry.ucla.edu; Tel: +1 3108259460

Accepted 21 June 2012

DOI: $10.1038 /$ sj.bdj.2012.1040

${ }^{\circledR}$ British Dental Journal 2012; 213: 501-508

\section{INTRODUCTION}

Despite progress made in caries control worldwide by the protective effects of fluoride, increased dissemination of oral hygiene information and widespread healthy diet education, dental caries still remains the most common chronic childhood disease. Consequently, it is a major financial burden on society in many countries throughout the world. In recent years, reports show that caries in the primary dentition has been increasing in the USA, UK, Canada, Australia, the Netherlands and other countries. ${ }^{1-8}$

Early childhood caries (ECC) is more prevalent among young children from low socioeconomic, ethnic minority populations. ${ }^{9}$ This uneven distribution occurs in many developed countries with 25\% of children bearing $75 \%$ of the affected surfaces. Dental caries is a preventable and transmissible infectious disease; it is well documented that the presence of caries in the primary dentition is one of the best indicators for future caries in the permanent dentition. ${ }^{10,11}$ Thus, the early and accurate identification of children at risk is of great importance for cost-effective caries control. Signs of ECC can be detected soon after the eruption of the first tooth. If risk indicators are identified early and oral health preventive practices are implemented at a young age, the disease can be controlled and its progression slowed.

In the USA, the American Dental Association (ADA), the American Academy of Paediatric Dentistry (AAPD), the American Academy of Paediatrics (AAP), the American Association of Public Health Dentistry (AAPHD) and the Academy of General Dentistry (AGD) all recommend that a child should see a dentist and establish a 'dental home' by one year of age or when the first tooth erupts. ${ }^{12-16}$ A dental home is defined as the ongoing relationship between the dentist and the patient where accessible and coordinated oral healthcare can be delivered comprehensively while actively involving family participation. ${ }^{17}$ Despite the widespread advocacy of a 'medical' and a 'dental home' by age one, infant oral health visits have not yet been 
embraced universally by practicing clinicians. Many paediatricians are unaware of current oral health evidence-based protocols and recommendations and refer children only when there is clinical evidence of established dental disease. Since family physicians and paediatricians often see children up to six times before age two, it is crucial to take these appointments as opportunities to increase awareness of oral health evaluations and screen young children for caries risk and refer for dental care. ${ }^{18}$ However, general dentists have to be prepared to accept these young children for their first dental visit's evaluation and treatment. This article presents an updated, simple and systematic six-step protocol for an infant oral examination that will ease implementation of early visits into dental practice. ${ }^{19}$ Due to the infectious and transmissible nature of dental caries, the first step in preventing the development of ECC is to provide perinatal oral healthcare to expectant mothers as soon as possible.

\section{PERINATAL ORAL HEALTH}

Caries is a transmissible, infectious disease. If this disease keeps progressing, surface cavitation and destruction of dental tissue worsens over time. The mutans streptococci (MS) group of bacteria (primarily streptococcus mutans and streptococcus sobrinus) are key pathogens in the caries process, due to their ability to adhere to smooth tooth surfaces and produce acid..$^{20}$ Generally, colonisation of MS in the oral cavity of children is the result of transmission of these organisms from the child's primary caregiver. ${ }^{21} \mathrm{~A}$ direct relationship exists between MS levels in adult caregivers and that of caries prevalence in their children. ${ }^{22}$ Factors influencing colonisation include frequent sugar exposure in the infants and habits that allowed salivary transfer from mother/caregiver to infants. Maternal factors, such as high levels of MS, poor oral hygiene, low socioeconomic status and frequent snacking increase the risk of bacterial transmission to her infant. ${ }^{23}$ Infants have been identified with high levels of MS in their mouths even before the eruption of the first tooth. ${ }^{19}$ Therefore, it is critical to consider an infant oral care programme in the context of a participating pair or mother-and-child dyad, which includes comprehensive maternal perinatal oral healthcare, counselling and treatment.

Table 1 CAMBRA for dental providers (0-5 years) assessment tool**

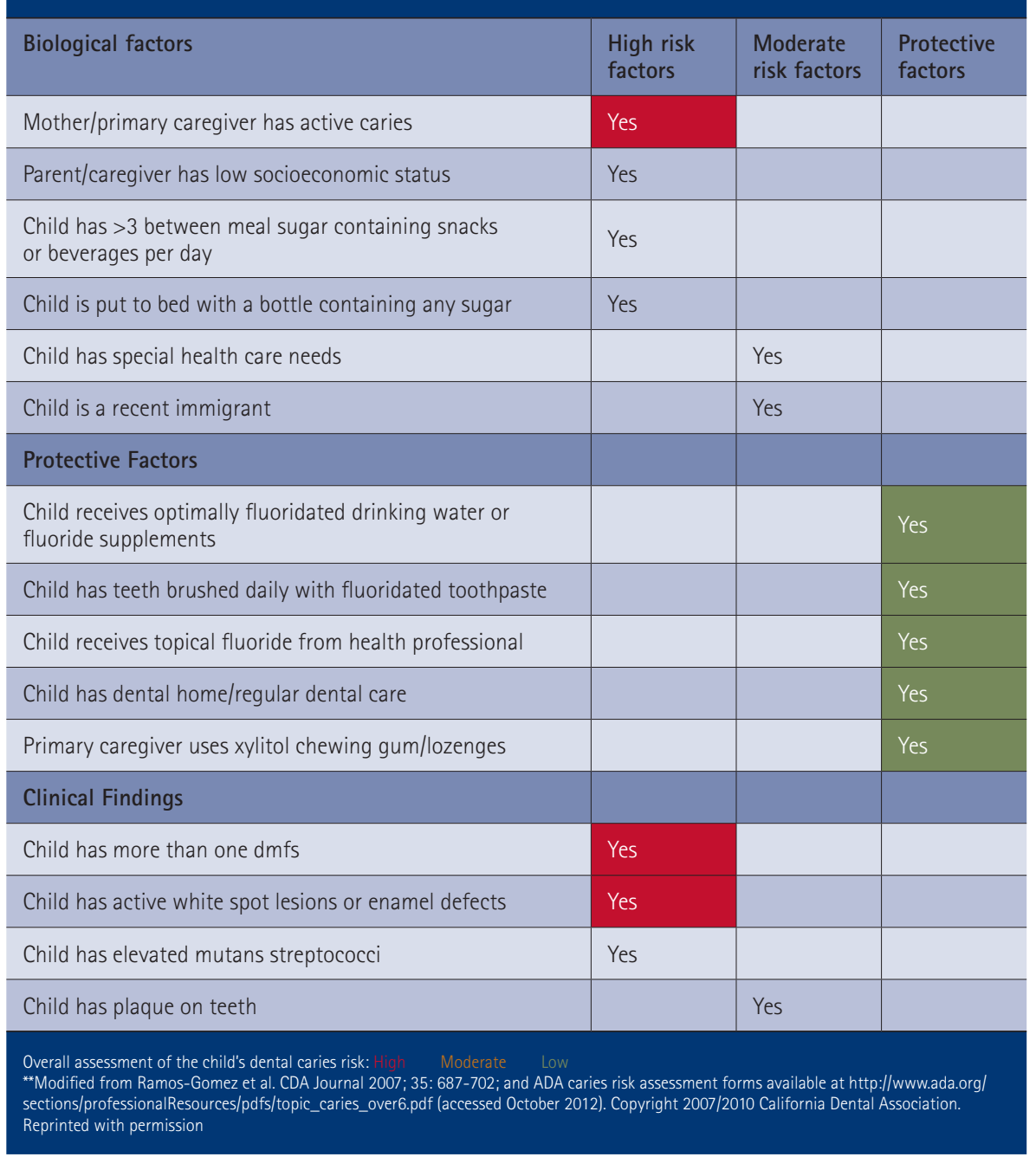

Dental professionals are beginning to recognise the essential role a mother plays in ensuring her child's oral health. Improving expectant mothers' oral health by reducing pathogenic bacteria levels in their own mouths, will delay the acquisition of oral bacteria and the development of ECC in their children. ${ }^{20}$ Restoring carious lesions, by itself, is insufficient to reduce a mother's risk of transmitting cariogenic bacteria to her offspring. An effective perinatal program should institute practices such as therapeutic interventions and lifestyle modification counselling both during pre- and post-partum to reduce maternal MS and lactobacilli levels. ${ }^{24}$ Unfortunately, pregnant women often do not receive oral healthcare and education in a timely manner. Many women do not know they should seek dental care during their pregnancy. Of those who do, they often encounter dentists unwilling to provide care to pregnant mothers. New mothers are also more likely to be receptive to ideas that would improve their offspring's oral health, ${ }^{25}$ making this the best 'window of opportunity' for preventive care. Therefore, dental, medical and obstetric providers have the prime opportunity to educate mothers with positive reinforcement and effective behavioural changes that could affect significantly their children's future oral health.

\section{INITIAL INFANT ORAL CARE VISIT}

Infants and parents (caregivers) will benefit from an early infant oral health visit and the establishment of a 'dental home'. An infant oral health visit should include caries risk assessment, individualised preventive strategies and anticipatory guidance. ${ }^{26,27}$ Establishing periodicity supervision of care intervals and age-appropriate 'care paths' is determined based on the risk of disease of each individual patient. ${ }^{28}$ Infants and toddlers are not expected to be cooperative during an oral examination; crying and movement are common responses. 
Explaining to the caregivers exactly what to expect during this visit and engaging them to participate may allay some of their fears and concerns.

An infant oral health visit consists of a six-step protocol:

1. Caries risk assessment

2. Proper positioning of the child

(knee-to-knee exam)

3. Age appropriate tooth brushing prophylaxis

4. Clinical examination of the child's oral cavity and dentition

5. Fluoride varnish treatment

6. Assignment of risk, anticipatory guidance and counselling.

\section{Caries risk assessment}

An individualised risk assessment of an infant or toddler for developing caries serves as the foundation for healthcare providers and parents/caregivers to identify and understand the child's ECC risk factors. A systematic assessment of caries risk serves as a guide for dentists to design treatment and preventive protocols for children already with disease and those deemed at risk. For optimal outcomes, caries risk assessment should be done as early as possible, and preferably before the onset of the disease process. Due to the fact that caries in the primary dentition is a strong predictor of caries in the permanent dentition, caries risk assessment and management is crucial, as is the subsequent follow-up. ${ }^{29,30}$ The caries balance concept states that the progression or reversal of dental caries is determined by the balance between pathological factors and caries protective factors. ${ }^{31-33}$ Risk factors are determined from an interview with the parent and from a clinical assessment of the child (Table 1).

During the interview with the parent/ caregiver, the assessment should explore biological and lifestyle risk factors that contribute to the development or progression of caries. Examples of risk factors include recently placed dental restorations in the mother, low socioeconomic status of the family, low health literacy of caregiver, the child's frequent intake of fermentable carbohydrates, sleeping with a bottle that contains liquids other than water and prolonged use of a 'sippy cup' containing milk, juice or a sweetened beverage.
Clinical disease indicators from oral examinations are used to diagnose caries. These include cavitated carious lesions, white spot lesions/decalcifications observed visually or by radiographs and recent restorations. However, these physical manifestations of caries do not tell us why the disease is present (Fig. 1). In the three clinical cases presented in Figure 1, the clinical signs (carious lesions at different clinical stages) indicate the presence of active carious processes. The caries risk assessment and the determination of the pathological factors, in particular, will guide the decision-making and the customisation of the therapeutic and the prevention strategies, specific to each patient.

Biological risk factors, also known as pathological factors, include presence of plaque, gingival bleeding (an indicator of dense plaque), low $\mathrm{pH}$ and dry mouth. Any of these recorded indicators can be then combined with the data from the interview to determine the risk for that patient (Fig. 2). In older children, the presence of dental or orthodontic appliances increases plaque retention and the risk for caries.

Protective factors, which are indicators that may reduce a child's risk for ECC, can also be assessed during the interview with the parent. These factors include optimal exposure to fluoride, access to regular dental care (for example, the presence of a dental home), consistent brushing with fluoride toothpaste, use of fluoridated tap water and xylitol among other combination therapy.

\section{Proper positioning}

Proper positioning of the child is critical to conducting an effective and efficient clinical exam in a young child. In general, the knee-to-knee position should be used with children aged six months to three years, or up to age five with children who have special healthcare needs. Children older than three years may be able to sit forward on their caregiver's lap or sit alone in a chair. Examiners and caregivers need to work together to transition the child smoothly from the interview to the exam (Fig. 3).

The clinician should explain what will happen (tell, show and do) before starting, and anticipate that young children may cry since crying is developmentally appropriate for children of this age. Knee-toknee positioning allows the child to see the

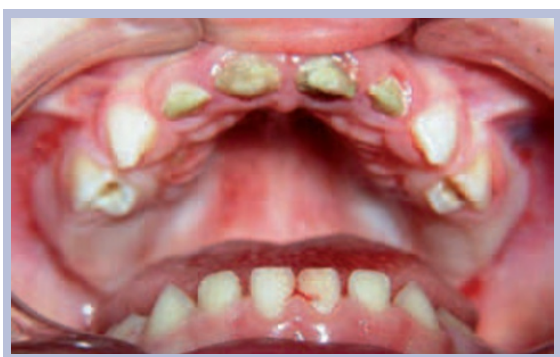

Fig. 1a Carious lesions at different clinical stages: child, 18 months old, with advanced cavitated lesions

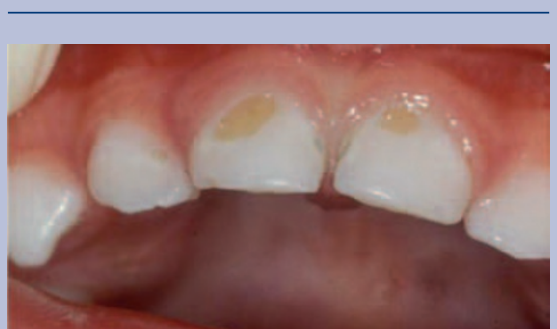

Fig. $1 \mathrm{~b}$ Child, three years old, with cavitated lesions localised on the buccal surfaces of the anterior maxillary teeth

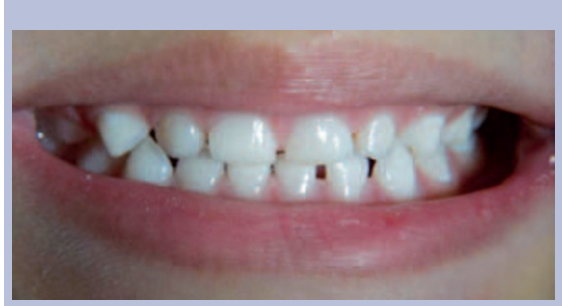

Fig. 1c Child, three years old, with cervical white spot lesions (reversible enamel lesions) localised on the canines and posterior teeth

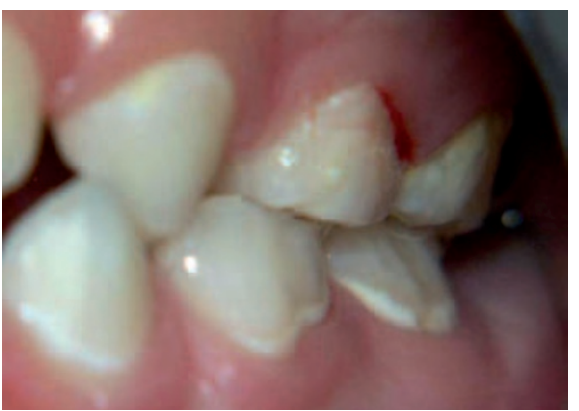

Fig. 2 Biological risk factors. Three-year-old child, with high caries risk. Presence of visible dental plaque, gingival bleeding and cervical white spots lesions on the posterior teeth

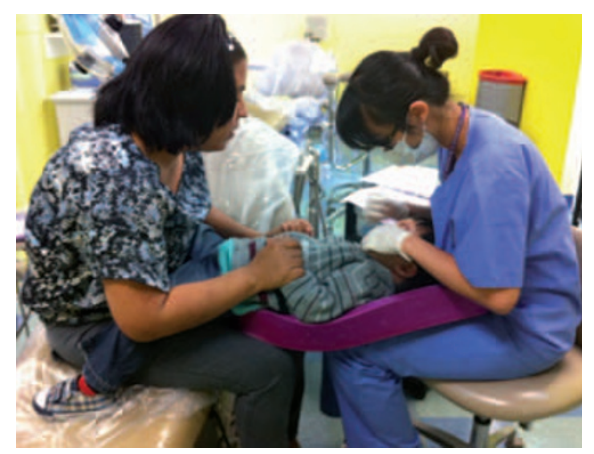

Fig. 3 The knee-to-knee position 


\begin{tabular}{|c|c|c|c|c|c|}
\hline \multirow{2}{*}{$\begin{array}{l}\text { Risk category } \\
\text { (ages } 0 \text { to } \\
2 \text { years) }\end{array}$} & \multicolumn{3}{|l|}{ Diagnostic } & \multirow[b]{2}{*}{ Fluoride } & \multirow{2}{*}{$\begin{array}{l}\text { Preventive intervention } \\
\text { Xylitol }\end{array}$} \\
\hline & Periodic oral exams & Radiographs & Saliva test & & \\
\hline Low & Annual & $\begin{array}{l}\text { Posterior bitewings at } 12-24 \text { month } \\
\text { intervals if proximal surfaces cannot } \\
\text { be examined visually or with a probe }\end{array}$ & Optional baseline & $\begin{array}{l}\text { In office: no } \\
\text { Home: brush twice a day w/ smear of } F \\
\text { toothpaste }\end{array}$ & Not required \\
\hline Moderate & Every six months & $\begin{array}{l}\text { Posterior bitewings at } 6-12 \text { month } \\
\text { intervals if proximal surfaces cannot } \\
\text { be examined visually or with a probe }\end{array}$ & Recommended & $\begin{array}{l}\text { In office: } F \text { varnish initial visit \& recalls } \\
\text { Home: Brush twice a day w/smear of F } \\
\text { toothpaste } \\
\text { Caregiver: OTC sodium fluoride treat- } \\
\text { ment rinses }\end{array}$ & $\begin{array}{l}\text { Child: xylitol wipes } \\
\text { Caregiver: two sticks of gum } \\
\text { or two mints four times a day }\end{array}$ \\
\hline $\begin{array}{l}\text { Moderate; } \\
\text { non-compliant }\end{array}$ & Every three to six months & $\begin{array}{l}\text { Posterior bitewings at } 6-12 \text { month } \\
\text { intervals if proximal surfaces cannot } \\
\text { be examined visually or with a probe }\end{array}$ & Required & $\begin{array}{l}\text { In office: F varnish initial visit \& recalls } \\
\text { Home: Brush twice a day w/smear of } \\
\text { F toothpaste combined w/smear of } \\
900 \mathrm{ppm} \text { calcium- phosphate paste } \\
\text { leave-on at bedtime Caregiver: OTC } \\
\text { sodium fluoride treatment rinses }\end{array}$ & $\begin{array}{l}\text { Child: xylitol wipes } \\
\text { Caregiver: two sticks of gum } \\
\text { or two mints four times a day }\end{array}$ \\
\hline High & Every three months & $\begin{array}{l}\text { Anterior (\#2 occlusal film) and } \\
\text { posterior bitewings at } 6-12 \text { month } \\
\text { intervals if proximal surfaces cannot } \\
\text { be examined visually or with a probe }\end{array}$ & Required & $\begin{array}{l}\text { In office: F varnish initial visit \& recalls } \\
\text { Home: Brush twice a day w/smear of } \\
\text { F toothpaste combined w/smear of } \\
900 \text { ppm calcium- phosphate paste } \\
\text { leave-on at bedtime Caregiver: OTC } \\
\text { sodium fluoride treatment rinses }\end{array}$ & $\begin{array}{l}\text { Child: xylitol wipes } \\
\text { Caregiver: two sticks of gum } \\
\text { or two mints four times a day }\end{array}$ \\
\hline $\begin{array}{l}\text { High; } \\
\text { non-compliant }\end{array}$ & Every one to three months & $\begin{array}{l}\text { Anterior (\#2 occlusal film) and } \\
\text { posterior bitewings at } 6-12 \text { month } \\
\text { intervals if proximal surfaces cannot } \\
\text { be examined visually or with a probe }\end{array}$ & Required & $\begin{array}{l}\text { In office: F varnish initial visit \& recalls } \\
\text { Home: Brush twice a day w/smear of } \\
\text { F toothpaste combined w/smear of } \\
900 \text { ppm calcium- phosphate paste } \\
\text { leave-on at bedtime Caregiver: OTC } \\
\text { sodium fluoride treatment rinses }\end{array}$ & $\begin{array}{l}\text { Child: xylitol wipes } \\
\text { Caregiver: two sticks of gum } \\
\text { or two mints four times a day }\end{array}$ \\
\hline Extreme & Every one to three months & $\begin{array}{l}\text { Anterior (\#2 occlusal film) and } \\
\text { posterior bitewings at } 6-12 \text { month } \\
\text { intervals if proximal surfaces cannot } \\
\text { be examined visually or with a probe }\end{array}$ & Required & $\begin{array}{l}\text { In office: F varnish initial visit and recalls } \\
\text { Home: Brush twice a day w/smear of } \\
\text { F toothpaste combined w/smear of } \\
900 \text { ppm calcium- phosphate paste } \\
\text { leave-on at bedtime Caregiver: OTC } \\
\text { sodium fluoride treatment rinses }\end{array}$ & $\begin{array}{l}\text { Child: xylitol wipes } \\
\text { Caregiver: two sticks of gum } \\
\text { or two mints four times a day }\end{array}$ \\
\hline
\end{tabular}

parent throughout the exam. It also allows the parent/caregiver to observe clinical findings and hygiene demonstrations directly, while gently helping to stabilise the child safely for the clinical examination. If the child can perceive a friendly and comfortable interaction between the clinician and caretaker, he or she will be more likely to cooperate and result in a smoother examination.

\section{Toothbrush prophylaxis}

Toothbrush prophylaxis is efficient in removing plaque in most young children. It is non-threatening to young children and serves to demonstrate the proper technique of brushing to the caregiver. The examiner retracts the child's lips and cheeks and demonstrates brushing along the gingival margins. The spongy handle of an age-appropriate sized toothbrush can be used to prop open the child's mouth. The handle of a second toothbrush can be used as a mouth prop. During this 'tellshow-do' encounter, the caregiver should be encouraged to brush their child's teeth at least twice a day, especially before bedtime. The use of fluoride toothpaste should be emphasised since fluoride has been shown to be effective topically to prevent caries. Parents and caregivers should be instructed to use a 'pea-sized' amount of fluoride toothpaste for children age two to six and a 'smear' for children under age two. ${ }^{34,35}$

\section{Clinical examination}

The examiner 'counts' the child's teeth aloud, using the toothbrush handle as a mouth prop if necessary. Many providers make a game of this task, singing songs, engaging the child's attention, and if all else fails, distracting the child with a brightly coloured toothbrush or toy. Praise the child at each step for their cooperation and/or good behaviour. While 'counting' the teeth, the examiner also inspects the soft tissues, hard tissues and occlusion, if the child is able to cooperate. Data from the clinical exam results should be combined with data from the caregiver interview to determine the child's overall caries risk and establish an oral diagnosis and formulate an individualised care (treatment) plan.

The following information should be documented:

- Visible plaque and its location

- White spot lesions

- Brown spots that on the occlusal surfaces may indicate caries

- Tooth defects, deep pits/fissures, tooth anomalies

- Missing and decayed teeth

- Existing restorations

- Defective restorations

- Gingivitis or other soft tissue abnormalities

- Occlusion

- Indications of trauma.

\section{Fluoride treatment}

Fluoride is an important and cost-effective prevention method to strengthen tooth enamel and prevent caries. The ADA and the UK NHS Department of Health recommends that high caries risk children receive a full-mouth topical fluoride varnish (FV) 


\begin{tabular}{|c|c|c|c|c|c|}
\hline & & & & & Restoration \\
\hline Sealants & Antibacterials & $\begin{array}{l}\text { Anticipatory guidance/ } \\
\text { counselling }\end{array}$ & Self-management goals & $\begin{array}{l}\text { White spot/precavitated } \\
\text { lesions }\end{array}$ & Existing lesions \\
\hline No & No & Yes & No & $n / a$ & n/a \\
\hline $\begin{array}{l}\text { Fluoride releasing sealants } \\
\text { recommended on deep pits } \\
\text { and fissures }\end{array}$ & No & Yes & No & $\begin{array}{l}\text { Treat } w / \text { fluoride products } \\
\text { as indicated to promote } \\
\text { remineralisation }\end{array}$ & $n / a$ \\
\hline $\begin{array}{l}\text { Fluoride releasing sealants } \\
\text { recommended on deep pits } \\
\text { and fissures }\end{array}$ & Recommend for caregiver & Yes & Yes & $\begin{array}{l}\text { Treat w/ fluoride products } \\
\text { as indicated to promote } \\
\text { remineralisation }\end{array}$ & $n / a$ \\
\hline $\begin{array}{l}\text { Fluoride releasing sealants } \\
\text { recommended on deep pits } \\
\text { and fissures }\end{array}$ & Recommend for caregiver & Yes & Yes & $\begin{array}{l}\text { Treat } w / \text { fluoride products } \\
\text { as indicated to promote } \\
\text { remineralisation }\end{array}$ & $\begin{array}{l}\text { ITR (interim therapeutic } \\
\text { restorations) or conventional } \\
\text { restorative treatment as } \\
\text { patient cooperation and family } \\
\text { circumstances allow }\end{array}$ \\
\hline $\begin{array}{l}\text { Fluoride releasing sealants } \\
\text { recommended on deep pits } \\
\text { and fissures }\end{array}$ & Recommend for caregiver & Yes & Yes & $\begin{array}{l}\text { Treat w/ fluoride products } \\
\text { as indicated to promote } \\
\text { remineralisation }\end{array}$ & $\begin{array}{l}\text { ITR or conventional restorative } \\
\text { treatment as patient } \\
\text { cooperation and family } \\
\text { circumstances allow }\end{array}$ \\
\hline $\begin{array}{l}\text { Fluoride releasing sealants } \\
\text { recommended on deep pits } \\
\text { and fissures }\end{array}$ & Recommend for caregiver & Yes & Yes & $\begin{array}{l}\text { Treat w/ fluoride products } \\
\text { as indicated to promote } \\
\text { remineralisation }\end{array}$ & $\begin{array}{l}\text { ITR or conventional restorative } \\
\text { treatment as patient } \\
\text { cooperation and family } \\
\text { circumstances allow }\end{array}$ \\
\hline
\end{tabular}

application and re-application consistently at three/four-month intervals. ${ }^{36} \mathrm{~A}$ minimum of every six months is recommended for children at moderate caries risk even if the child lives in a community that already receives the benefits of water fluoridation. The provider should reiterate the cumulative benefit of the fluoride varnish, even if it has been mentioned earlier in the visit. After application, the caregiver should be reminded not to allow the child to brush their teeth or to eat crunchy/sticky foods for the rest of the day to allow fluoride varnish to be effective.

$\mathrm{FV}$ is one of the most efficacious and prevalent methods used by modern dentists to combat early childhood caries. According to the ADA, extensive research has shown FV to be safe and effective for patients of all ages. ${ }^{37} \mathrm{FV}$ is painless, quick to apply, and therefore can be used on very young children. ${ }^{38}$ There is, however, widespread debate on the results in reference to differing recommendations for the frequency and periodicity of FV application. Some sources advocate FV treatments every six months, citing this protocol as the most cost-effective method with the best outcome. ${ }^{39}$ Others argue that three consecutive varnishes over a week's time-period, once annually, are more effective than semi-annual treatments. ${ }^{40-42}$ Regardless, all sources agree that FV is useful as a necessary standard of care component for the prevention of dental caries and crucial as a tool in oral health maintenance for all ages. ${ }^{40-42}$

\section{Assignment of risk, anticipatory guidance and counselling}

An individualised care plan for each infant/ caregiver is designed based upon the risk determined from the parent interview and the clinical examination of the child (Tables 2 and 3). A dual approach is essential for moderate and high caries risk children and their parent/caregivers. Strategies need to be employed to decrease the maternal or caregiver transmission of cariogenic bacteria to infants through the potential use of chlorhexidine rinse and xylitol products for caregivers, and fluoride varnish for both the caregiver and the child. ${ }^{34}$ Additionally, the necessary changes in the child's diet, tooth brushing and fluoride application can be identified from the risk analysis.

The science of caries prevention continues to evolve. Table 2 illustrates how to develop care paths for a practice's patients. There are many alternative approaches to the prevention and treatment of dental caries, with more emerging continuously. Care paths should remain dynamic and change over time as the effectiveness of new as well as current protocols is validated by scientific evidence.

Parents should be given additional information and anticipatory guidance on oral health prevention that is specific to the needs of their child. Such information includes oral hygiene, growth and development issues (that is, teething, digit or dummy habits), oral habits, diet and nutrition and injury prevention (Tables 2 and 3). The anticipatory guidance approach is designed to take advantage of time-critical opportunities to implement preventive health practices and reduce the child's risk of preventable oral disease. ${ }^{43-45}$ 
An important component of the visit is to counsel the parents to change specific factors which may contribute to active caries or to an increased caries risk in their child. Traditionally, generic recommendations, such as 'brush your teeth twice a day and don't eat sweets', have been offered to parents with limited success. Using family-centred, customised recommendations have been shown to be more promising as parents are more engaged in changing specific practices. Motivational interviewing is a counselling technique that relies on two-way communication between the clinician and the patient or parent ${ }^{46}$ (Fig. 4). This includes establishing a therapeutic alliance (that builds rapport and trust), by asking questions to help parents identify the problem and listening to what they say, encouraging self-motivational statements, preparing for change (discussing the hurdles that interfere with action), responding to resistance and scheduling follow-up, as well as preparing the parent for the inevitable bumps in the road. ${ }^{47}$

Following the brief motivational interviewing (counselling), the parent/caregiver is asked to select two self-management goals or recommendations as their assignments before the next re-evaluation dental visit. The parent/caregiver is asked to commit to the two goals selected and is informed that the oral healthcare providers will follow-up on those goals with them at the next appointment (see Tables 2 and 3 for self-management goals for parent/caregiver).

\section{RECALL VISITS \\ AND RECALL PERIODICITY}

The clinician must consider each child's individual needs to determine the appropriate interval and frequency for oral examination; ${ }^{48}$ some infants and toddlers with high caries risk should be reevaluated on a monthly basis (Tables 2 and 3). Most children at high risk need to be seen on a three-month interval for re-evaluation. Those children in the moderate risk category need to be placed on a six-month interval and the low risk child at a 6-12 month range interval (Tables 2 and 3).

After the parent has been following the recommendations for three to six months, have them and their child come back for reassessment. Parents need encouragement

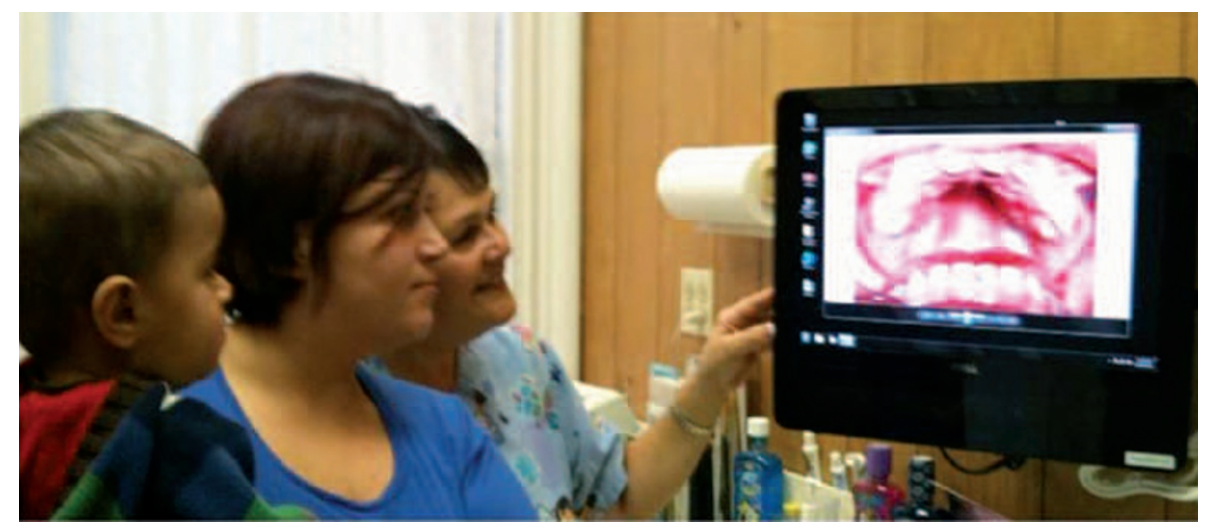

Fig. 4 The motivational interviewing (counselling)

early on when new behavioural change is required and time to ask questions regarding any difficulties with following the recommendations. They should be aware that changing home practices does not happen overnight. At these infant oral care visits, it is essential to reassess the risk status and monitor improvement on the previously set self-management goals. During these reassessment appointments, changes can be made and prevention protocols reinforced.

\section{CONCLUSIONS}

Paediatric dentists and general dentists have the most influential role in preventing and reducing the severity of early childhood caries in young children. By embracing the concepts of the 'dental home', perinatal and infant oral health, providers can implement preventive and treatment protocols. These care paths are based on individually determined caries risk and utilize an appropriate age-specific caries risk assessment. For example, care for very young children should include preventive interventions such as fluoride varnish applications, sealants and use of xylitol products. When restoration is required but can't be performed readily for a variety of reasons, practitioners should consider interim therapeutic restorations (ITR), employing the use of hand or slow speed rotary instruments for partial caries removal followed by the application of adhesive, fluoride releasing restoratives such as auto-curing resin-modified glass ionomer cement. ${ }^{49}$ Motivational interviewing, anticipatory guidance and setting self-management goals increases the probability for better oral health outcomes and behaviour, not just for the child, but for the whole family. Partnerships with other healthcare professionals with the aim of providing preventive care for our high risk populations is crucial to achieving better oral health outcomes in the future. The overall aim is to lower the risk level over time and eliminate the need for further restorations by controlling the caries process.

The authors would like to thank Claudie DamourTerrasson, publishing director of the Groupe Information Dentaire, Paris France, for the authorisation of translation and publication of the series in the BDJ; Dr Norman Tinanoff, Dr Manwai Ng for contributing their support and knowledge to this project; Ms Debra Tom for her editorial assistance; and the HRSA Oral Health Disparities Collaborative for the implementation of the CAMBRA instrument and the development of the self-management goal instrument through High Plains Health Center. Finally, they wish to acknowledge the AAPD and $A A P$ for their support and leadership on Caries Risk Assessment development.

1. World Health Organization. Oral health country/ area profile program (CAPP). Geneva: WHO, 2006 Online programme available at http://www.whocollab.od.mah.se/ (accessed October 2012).

2. Dye B A, Tan S, Smith V et al. Trends in oral health status: United States, 1988-1994 and 1999-2004. Vital Health Stat 11 2007: 1-92.

3. Pitts N B, Chestnutt I G, Evans D, White D, Chadwick $B$, Steele J G. The dentinal caries experience of children in the United Kingdom, 2003. Br Dent J 2006; 200: 313-320.

4. Al-Jewair T S, Leake J L. The prevalence and risks of early childhood caries (ECC) in Toronto, Canada. J Contemp Dent Pract 2010; 11: 1-8.

5. Armfield J M, Spencer A J. Changes in South Australian children's caries experience: is caries re-surfacing? Aust Dent J 2004; 49: 98-100.

6. Truin G J, van't Hof M A, Kalsbeek H, Frencken J E König K G. Secular trends of caries prevalence in 6and 12-year-old Dutch children. Community Dent Oral Epidemiol 1993; 21: 249-252.

7. Begzati A, Berisha M, Meqa K. Early childhood caries in preschool children of Kosovo - a serious public health problem. BMC Public Health 2010: 10: 788.

8. Ferro R, Besostri A, Meneghetti B et al. Oral Health inequalities in preschool children in North-Eastern Italy as reflected by caries prevalence. Eur J Paedr Dent 2007; 8: 13-18.

9. Vargas C M, Crall J J, Schneider D A Sociodemographic distribution of pediatric dental caries: NHANES III, 1988-1994. J Am Dent Assoc 1998; 129: 1229-1238.

10. Li Y, Wang W. Predicting caries in permanent teeth from caries in primary teeth: an eight-year cohort study. J Dent Res 2002; 81: 561-566.

11. Alm A, Wendt L K, Koch G, Birkhed D. Prevalence of approximal caries in posterior teeth in 15-year-old Swedish teenagers in relation to their caries 


\begin{tabular}{|c|c|c|c|c|}
\hline \multirow{2}{*}{$\begin{array}{l}\text { Risk category } \\
\text { Ages } 3 \text { to } 6\end{array}$} & \multicolumn{3}{|l|}{ Diagnostic } & \multirow[b]{2}{*}{ Fluoride } \\
\hline & $\begin{array}{l}\text { Periodic oral } \\
\text { exams }\end{array}$ & Radiographs & Saliva test & \\
\hline Low & Annual & $\begin{array}{l}\text { Posterior bitewings at } \\
12-24 \text { month intervals } \\
\text { if proximal surfaces } \\
\text { cannot be examined } \\
\text { visually or with a } \\
\text { probe }\end{array}$ & $\begin{array}{l}\text { Optional } \\
\text { Baseline }\end{array}$ & $\begin{array}{l}\text { In office: no } \\
\text { Home: Brush twice a day } \\
\text { w/ pea size of } F \text { toothpaste }\end{array}$ \\
\hline Moderate & $\begin{array}{l}\text { Every } \\
6 \text { months }\end{array}$ & $\begin{array}{l}\text { Posterior bitewings } \\
\text { at } 6-12 \text { month } \\
\text { intervals if proximal } \\
\text { surfaces cannot be } \\
\text { examined visually or } \\
\text { with a probe }\end{array}$ & Recommended & $\begin{array}{l}\text { In office: F varnish initial } \\
\text { visit and recalls } \\
\text { Home: Brush twice } \\
\text { a day w/pea- size of } \\
\text { F toothpaste } \\
\text { Caregiver: OTC Sodium } \\
\text { Fluoride treatment rinses }\end{array}$ \\
\hline $\begin{array}{l}\text { Moderate; } \\
\text { non-Compliant }\end{array}$ & $\begin{array}{l}\text { Every } \\
3-6 \text { months }\end{array}$ & $\begin{array}{l}\text { Posterior bitewings } \\
\text { at } 6-12 \text { month } \\
\text { intervals if proximal } \\
\text { surfaces cannot be } \\
\text { examined visually } \\
\text { or with a probe }\end{array}$ & Required & $\begin{array}{l}\text { In office: F varnish initial } \\
\text { visit and recalls } \\
\text { Home: Brush twice } \\
\text { a day w/pea- size of } \\
\text { F toothpaste combined } \\
\text { w/pea-size of } 900 \text { ppm } \\
\text { calcium- phosphate paste } \\
\text { leave-on } \\
\text { at bedtime } \\
\text { Caregiver: OTC sodium } \\
\text { fluoride treatment rinses }\end{array}$ \\
\hline High & $\begin{array}{l}\text { Every } \\
3 \text { months }\end{array}$ & $\begin{array}{l}\text { Anterior (\#2 occlusal } \\
\text { film) and posterior } \\
\text { bitewings at } \\
6-12 \text { month intervals } \\
\text { if proximal surfaces } \\
\text { cannot be examined } \\
\text { visually or with } \\
\text { a probe }\end{array}$ & Required & $\begin{array}{l}\text { In office: F varnish initial } \\
\text { visit and recalls } \\
\text { Home: Brush twice a day } \\
\text { w/pea-size of F toothpaste } \\
\text { combined w/pea-size } \\
\text { of } 900 \mathrm{ppm} \text { calcium- } \\
\text { phosphate paste leave-on } \\
\text { at bedtime } \\
\text { Caregiver: OTC sodium } \\
\text { fluoride treatment rinses }\end{array}$ \\
\hline $\begin{array}{l}\text { High; } \\
\text { non-Compliant }\end{array}$ & $\begin{array}{l}\text { Every } \\
1-3 \text { months }\end{array}$ & $\begin{array}{l}\text { Anterior (\#2 occlusal } \\
\text { film) and posterior } \\
\text { bitewings at } \\
6-12 \text { month intervals } \\
\text { if proximal surfaces } \\
\text { cannot be examined } \\
\text { visually or with } \\
\text { a probe }\end{array}$ & Required & $\begin{array}{l}\text { In office: F varnish initial } \\
\text { visit and recalls } \\
\text { Home: Brush twice } \\
\text { a day w/pea-size of } \\
\mathrm{F} \text { toothpaste combined } \\
\text { w/pea-size of } 900 \mathrm{ppm} \\
\text { calcium- phosphate paste } \\
\text { leave-on } \\
\text { at bedtime } \\
\text { Caregiver: OTC sodium } \\
\text { fluoride treatment rinses }\end{array}$ \\
\hline Extreme & $\begin{array}{l}\text { Every } \\
1-3 \text { months }\end{array}$ & $\begin{array}{l}\text { Anterior (\#2 occlusal } \\
\text { film) and posterior } \\
\text { bitewings at } \\
6-12 \text { month intervals } \\
\text { if proximal surfaces } \\
\text { cannot be examined } \\
\text { visually or with } \\
\text { a probe }\end{array}$ & Required & $\begin{array}{l}\text { In office: F varnish initial } \\
\text { visit \& recalls } \\
\text { Home: Brush twice } \\
\text { a day w/pea-size of } \\
\text { F toothpaste combined } \\
\text { w/pea-size of } 900 \text { ppm } \\
\text { calcium- phosphate paste } \\
\text { leave-on } \\
\text { at bedtime } \\
\text { Caregiver: OTC sodium } \\
\text { fluoride treatment rinses }\end{array}$ \\
\hline
\end{tabular}

experience at 3 years of age. Caries Res 2007; 41: 392-398.

12. American Dental Association. Statement on early chidlhood caries. Chicago: ADA, 2007. ADA. Online statement available at http://www.ada.org/2057. aspx (accessed October 2012).

13. American Academy of Pediatric Dentistry reference manual 2010-2011. Pediatr Dent 2010-2011; 32: 1-334.

14. Hale K J, American Academy of Pediatrics Section on Pediatric Dentistry. Oral health risk assessment timing and establishment of the dental home. Pediatrics 2003; 111: 1113-1116. First oral health assessment policy. AAPHD, 2004. Online policy available at http://www.aaphd.org/ default.asp?page=FirstHealthPolicy.htm (accessed October 2012).

16. Academy of General Dentistry. Policies, guidelines, positions statements and fact sheets. Online information available at http://www.agd.org/issuesadvocacy/policies/dentalcare/ (accessed October 2012).
15. American Association of Public Health Dentistry.
17. American Academy of Pediatric Dentistry. Definition of dental home. Chicago: AAPD, 2006 http://www. aapd.org/media/policies_guidelines/d_dentalhome. pdf (accessed October 2012)

18. Ismail A I, Nainar S M, Sohn W. Children's first dental visit: attitudes and practices of US pediatricians and family physicians. Pediatr Dent 2003; 25: 425-430.

19. Ramos-Gomez F, Ng M W. Six step protocol for a successful infant oral care visit. Pediatric dentistry today, 2009. http://www.cdhp.org/resource/six step_protocol_successful_infant_oral_care_visit (accessed October 2012).

20. Ramos-Gomez F. Bacterial salivary markers' role in ECC risk assessment in infants. J Dent Res 2006; 85B: poster 0516.

21. Seki M, Yamashita Y, Shibata Y, Torigoe $H_{1}$ Tsuda $H$, Maeno M. Effect of mixed mutans streptococci colonization on caries development. Oral Microbiol Immunol 2006; 21: 47-52.

22. Douglass J M, Li Y, Tinanoff N. Association of mutans streptococci between caregivers and their children. Pediatr Dent 2008; 30: 375-387.

23. Tinanoff N, Kanellis M J, Vargas C M. Current understanding of the epidemiology mechanisms, and prevention of dental caries in preschool children. Pediatr Dent 2002; 24: 543-551.

24. California Dental Association Foundation, American College of Obstetricians and Gynecologists, District I X. Oral health during pregnancy and early childhood: evidence-based guidelines for health professionals. J Calif Dent Assoc 2010; 38: 391-403, 405-440.

25. Gajendra S, Kumar J V. Oral health and pregnancy: a review. N Y State Dent J 2004; 70: 40-44.

26. American Academy of Pediatric Dentistry, American Academy of Pediatrics, American Academy of Pediatric Dentistry Council on Clinical Affairs. Policy on early childhood caries (ECC): classifications, consequences, and preventive strategies. Pediatr Dent 2005-2006; 27: 31-33.

27. American Academy of Pediatric Dentistry, American Academy of Pediatrics. Policy on early childhood caries (ECC): classifications, consequences, and preventive strategies. Pediatr Dent 2008-2009; 30: 40-43.

28. Peretz B, Ram D, Azo E, Efrat Y. Preschool caries as an indicator of future caries: a longitudinal study. Pediatr Dent 2003; 25: 114-118.

29. Tagliaferro E P, Pereira A C, Meneghim Mde C, Ambrosano G M. Assessment of dental caries predictors in a seven-year longitudinal study. J Public Health Dent 2006; 66: 169-173.

30. Featherstone J D. The caries balance: contributing factors and early detection. J Calif Dent Assoc 2003 31: 129-133.

31. Featherstone J D, Adair S M, Anderson M H et al. Caries management by risk assessment: consensus statement, April 2002. J Calif Dent Assoc 2003; 31: 257-269.

32. Featherstone J D. The caries balance: the basis for caries management by risk assessment. Oral Health Prev Dent 2004; 2: 259-264.

33. Featherstone $J \mathbf{D}$. Caries prevention and reversal based on the caries balance. Pediatr Dent 2006; 28: 128-132.

34. Ramos-Gomez F J. Clinical considerations for an infant oral health care program. Compend Contin Educ Dent 2005; 26: 17-23.

35. Recommendations from MCHB Expert Panel. Topical fluoride recommendations for high-risk children development of decision support matrix. Altarum Institute, Washington: 2007. Online article available at http://www.ncdhhs.gov/dph/oralhealth/library/ includes/IMBresources/TopicalFluorideRpt\%20 4-30-09\%20edited\%20with\%20link\%201-10.pdf (accessed October 2012).

36. American Dental Association Council on Scientific Affairs. Professionally applied topical fluoride: evidence-based clinical recommendations. J Dent Educ 2007: 71: 393-402.

37. Autio-Gold J. Recommendations for fluoride varnish use in caries management. Dent Today 2008; 27: 64-67.

38. Moberg Sköld U, Petersson L G, Lith A, Birkhed D. Effect of school-based fluoride varnish programmes on approximal caries in adolescents from different 
caries risk areas. Caries Res 2005; 39: 273-279.

39. Irigoyen M E, Luengas I, Zepeda M A, Sánchez-Pérez $\mathrm{L}$ T. Frequency of fluoride varnish application in prevention of dental caries. Xochimilco, Mexico: Universidad Autonoma Metropolitana.

40. Marinho V C. Higgins J P, Logan S, Sheiham A. Fluoride varnishes for preventing dental caries in children and adolescents. Cochrane Database Syst Rev 2002: CD002279.

41. Marinho V C, Higgins J P, Logan S, Sheiham A Topical fluoride (toothpastes, mouthrinses, gels or varnishes) for preventing dental caries in children and adolescents. Cochrane Database Syst Rev 2003: CD002782.

42. Marinho V C, Higgins J P, Sheiham A, Logan S. One topical fluoride (toothpastes, or mouthrinses, or gels, or varnishes) versus another for preventing dental caries in children and adolescents. Cochrane
Database Syst Rev 2004: CD002780.

43. American Academy of Pediatric Dentistry Clinical Affairs Committee, American Academy of Pediatric Dentistry Council on Clinical Affairs. Guideline on periodicity of examination, preventive dental services, anticipatory guidance/counseling, and ora treatment for infants, children, and adolescents. Pediatr Dent 2008; 30: 112-118.

44. American Academy of Pediatric Dentistry Clinical Affairs Committee, American Academy of Pediatric Dentistry Council on Clinical Affairs. Guideline on periodicity of examination, preventive dental services, anticipatory guidance, and oral treatment for children. Pediatr Dent 2005-2006; 27: 84-86.

45. American Academy of Pediatric Dentistry. Clinical guideline on periodicity of examination, preventive dental services, anticipatory guidance, and oral treatment for children. Pediatr Dent 2004;
26: 81-83.

46. Weinstein $P$, Harrison R, Benton T. Motivating parents to prevent caries in their young children: one-year findings. J Am Dent Assoc 2004; 135: 731-738.

47. Weinstein P. Provider versus patient-centered approaches to health promotion with parents of young children: what works/does not work and why. Pediatr Dent 2006; 28: 172-176.

48. Ramos-Gomez F J, Crall J, Gansky S A, Slayton R L, Featherstone J D. Caries risk assessment appropriate for the age 1 visit (infants and toddlers). J Calif Dent Assoc 2007; 35: 687-702.

49. American Academy on Pediatric Dentistry Clinical Affairs Committee- Restorative Dentistry Subcommittee, American Academy on Pediatric Dentistry. Council on Clinical Affairs Guideline on pediatric restorative dentistry. Pediatr Dent 20082009: 30: 163-169.

\section{Erratum}

Practice article (BDJ 2012; 213: 447-451)

'Minimal intervention dentistry: part 2. Caries risk assessment in adults'

In the above practice article, the original article was actually adapted from: Fontana M, Gonzalez-Cabezas C. Evaluation du risque carieux chez l'adulte. Réalités Cliniques 2011; 22: 213-219.

We apologise for any confusion caused by this error. 